but has hard shell. Spanish Bunch is even earlier, but with smaller yield. The ground-nut responds markedly to plant selection, which has been done in East Africa for some years with occasional notable success ; for example, in evolving wilt-resistant strains. As it is not a self-fertile plant, selection and isolation of new strains is comparatively easy. Selection has been mostly directed to high yield and kernel percentage, with resistance to rosette disease ; but not, so far as is known, to evenness in ripening-lack of which often causes serious trouble in harvesting - or to long dormancy and high oil content. In Uganda, bunch types are encouraged, but selection is proceeding with creeping types owing to their resistance to locusts. Selection has resulted in higher yielding varieties in some areas; but owing to the varying behaviour of different selections depending on season, final choice is difficult. In Nigeria, selection over five years resulted in 25 per cent yield increase in bunch type and 16 per cent in creeping type. Work with existing East African types is thought to be better than with imported varieties.

The best soils are light, sandy, well-drained loams, not too rich in organic matter; addition of lime and phosphate is often beneficial. The ground-nut fits in well with several different rotations, including cotton and maize. Fairly close spacing to keep the ground well covered is important, and weeds are often allowed to grow for this purpose. Yields per acre vary enormously according to conditions : from 200 to $2,200 \mathrm{lb}$. unshelled on native farms, though the average is nearer $600 \mathrm{lb}$., which is slightly less than the yield obtained in the United States. Mechanized farming in Queensland gives 3,600 lb. unshelled.

Sesame (simsim, ufuta, gingelly, bene, or til) has also high oil content, usually about 50 per cent, but sometimes much higher, with about 20 per cent protein and 18 per cent carbohydrate. Calcium content in the undecorticated product is remarkably high (1 per cent, mostly in the seed-coat), while phosphorus is $0 \cdot 7$ per cent. The main sesame areas in East Africa are : southern province of Tanganyika, northern province of Uganda, and Nyanza province of Kenya. It is mostly grown by native farmers for their own use, and the average yield is 350-400 lb. per acre. Care has to be taken not to contaminate with wild sesame (S. radiatum or Ufuta mwitu), which contains a substance toxic to cattle. There are many varieties, but the principal types are white and black. In Uganda, selection has aimed at high. yielding white-seed types for export, and has resulted in some improvement; as also in Tanganyika. Soils and climate, cultivation, harvesting, storage, pests, etc., are described. From the economic point of view, the yield from sesame is only about one third that of ground-nuts, and it is a major crop only where soils are sticky and make ground-nut harvesting expen. sive. It does not interest European farmers greatly.

Sunflower. As is well known, this crop covers vast areas in the U.S.S.R., and to a less degree in the Argentine, the Balkans, and China. It is not grown to any large extent in Africa. The best known in the past have been the giant types with heads 12-22 in. across, but easily sensitive obviously to wind and rain. A dwarf type has been introduced in Britain and elsewhere, such as the Pole Star, Southern Cross, Jupiter, and Mars. Attempts are being made to obtain seed of these varieties for trial in East Africa; but whether it is economically feasible there depends on world prices. Some notes on cultivation, etc., are given.

\section{CHANK MARKING EXPERIMENTS AT TUTICORIN}

GOR the purpose of ascertaining the migrations and growth-rate of the chank, marking experiments were begun in 1931 by the Madras Fisheries Department*. Since then about 5,000 chanks have been marked and liberated on the chank beds of Tuticorin. It was thought that there might be a migration of chanks from those beds to the Ceylon beds on the other side of the Gulf of Mannar. The experiments have shown that such migrations do not take place; but there are movements of chanks from one bed to another in the immediate vicinity. The greatest distance covered by any marked chank was nine miles.

There is marked variation in observed rates of growth, some specimens showing very little increase over long periods, while others have grown as much as $23 \mathrm{~mm}$. in length in 23 months. The reason for this disparity is not known, but the suggestion is made that it may be due to variations in hydrological and other conditions on the different beds. This is a fairly safe guess, but it is no more than that. Much more work will have to be done and the data handled much more carefully and expertly before a sound knowledge of the bionomics of the chank can be acquired. It should not be necessary to state, for example, that of the 5,000 odd chanks that have been marked "only about 259 were recovered". Chanks are by no means minute animals, and the exact number recovered by the investigator must surely be known and should be recorded and reported upon with equal accuracy. In the absence of such accuracy little reliance can be placed upon any results obtained or conclusions reached.

Moreover, no scientific investigator should send out a paper in which only the local (common) name of the organism under investigation is given. Presumably the chank referred to in this paper is the gastropod Turbinella pyrum, Linn., but nowhere is this stated.

* Preliminary Study of the Chank Marking Experiments at Tuticorin. By K. Chidambaram and M. Mukandan Unny. A paper read before the Zoological Section of the Indian Science Congress, January 1947.

\section{FORTHCOMING EVENTS}

\author{
Monday; May 12
}

FARMers' CuUB (at the Royal Empire Society, Craven Street, Strand, London, W.C.2), at 2.30 p.m.-Mr. Martin Jones: "Ley Farming and the Livestock Population".

INSTITUTION OF POST OFFICE FLECTRICAL ENGINEERS (at the Institution of Electrical Engineers, Savoy Place, Victoria EmbankInstitution of Electrical Engineers, Savoy Place, Victoria Embankment, London, W.C.2), at 5 p.m.-Mr. W;

Soclety of PUBlic ANalysts aND other ANaLytical Chemists, BIOLOGICAL METHODS GROUP (in the West Hall, Royal Society of Medicine, 1 Wimpole Street, London, W.1), at 6 p.m.-Symposium on "The Production and Care of Laboratory Animals", Part 3. Dr. J. I. M. Jones and Dr. Eric C. Wood : "Housing"; General Discussion on all subjects.

Tuesday, May 13

ELECTRICAd Association FOR WOMEN (at the Connaught Rooms, Great Queen Street, London, W.C.2), at 10.30 a.m.-Fourteenth Annual General Meeting.

ZoOI.GICAL SOCIETY OF LONDON (at Regent's Park, London, N.W.8.), at 5 p.m. - Scientific Meeting.

INSTITUtion of EleCtRICAL ENGINEERS, RAdio SECTION (at Savoy Place, Victoria Embankment, London, W.C.2), at 5.30 p.m.-Discussion on "Future Trend of Component Design for the Services" (to be opened by Dr. G. W. Sutton and Mr. E. M. Lee).

IUIUMINATING ENGINEERING SOCIRTY (at the Institution of Mechanical Engineers, Storey's Gate, St. James's Park, London, S.W.1), at 6 p.m. "Annual General Meeting; at 6.30 p.m.-Dr. N. A. Ha 